\title{
A Biceps Muscle Latissimus dorsi in a Dog
}

\author{
Una Segunda Cabeza del Músculo Latissimus dorsi en un Perro
}

Julio Gil* \& Ricardo Olivares**

GIL, J. \& OLIVARES, R. A biceps muscle Latissimus dorsi in a dog. Int. J. Morphol., 32(4):1464-1466, 2014.

SUMMARY: This article reports the finding of a twin unreported muscle begin. In one dog, both, left and right muscle latissimus dorsi were biceps. The thin second head of $\mathrm{m}$. latissimus dorsi that we founded, could be an intermediate step of comparative anatomy changes from reptilian to mammal. Man breast surgery and cardiomyoplasty, use dog latissimus dorsi as experimental, to know this information can be useful to these situations.

KEY WORDS: Muscle; M. Latissimus dorsi; Dog; M. Biceps; Arm.

\section{INTRODUCTION}

The $\operatorname{dog}$ M. latissimus dorsi, is a flat and triangular muscle which lies on the dorsal half of the lateral thoracic wall. It begins from the spinous processes of the lumbar vertebra and the last seven or eight thoracic vertebra, by means of a wide tendinous leaf of the lumbodorsal fascia. The end of M. latissimus dorsi is in an aponeurosis on the humerus teres tubercle, with the tendon of the M.teres mayor, medially on the m. triceps. This muscle is innerved by Nn. pectorales caudales and N. thoracodorsalis (Sisson \& Grossman, 1963; Nickel et al., 1986; Schwarze, 1970; Dyce et al., 1999; Evans, 1993; Gil et al., 1997; Schaller et al., 1996).

\section{MATERIAL AND METHOD}

This M. latissimus dorsi second extra head is a fortuitous find during routine procedure of an anatomical dissection demonstration (Figs. 1 y 2).

Over a period of 20 years, a total of 300 crossbred adult dogs of variable weight, were routinely prepared for anatomical dissection, this is the first time we found this anomalous origin, which we did not find in any previous report.

The clinical history of this dog has no references about functional locomotor disturbance or any disease.

\section{RESULTS}

In this dog, both, left and right $M$. latissimus dorsi have a second extra head under its anatomically normal head (Fig. 1).

Each extra head is a flat thin muscle, lies on the dorsal half of the lateral thoracic wall, and it is covered to $M$. latissimus dorsi normal head. It begins from the spinous processes of six to eight thoracic vertebra, by mean a wide tendinous leaf of the lumbodorsal fascia, joint to the tendinous leaf of M. latissimus dorsi normal head (Fig. 1).

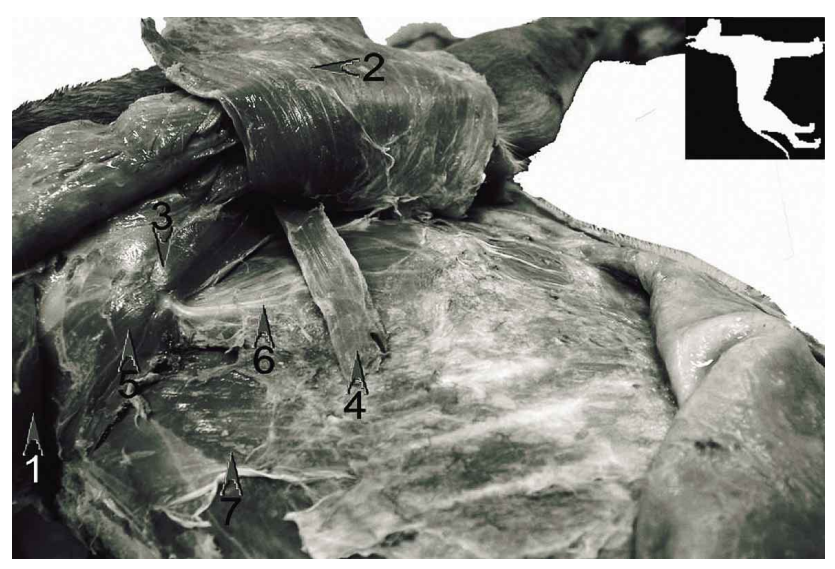

Fig. 1. Left side of the dog. M trapezius (1). M. latissimus dorsi (2). M. teres major (3). M. latissimus dorsi second venter (4). $M$. rhomboideus thoracis (5). M. serratus ventralis caudalis (6). $M$. serratus dorsalis cranialis (7).

\footnotetext{
* Department of Anatomy, Embryology and Animal Genetics, Faculty of Veterinary Medicine, University of Zaragoza, Spain.

** Department Animal Pathology. Faculty of Veterinary Science and Livestock, University of Chile, Santiago, Chile.
} 
The end of second extra head of M. latissimus dorsi is a short aponeurosis together m. latissimus dorsi normal head.

This second muscle head is innerved as latissimus dorsi normal head, by nn. pectorales caudales and $N$. thoracodorsalis (Fig. 2).

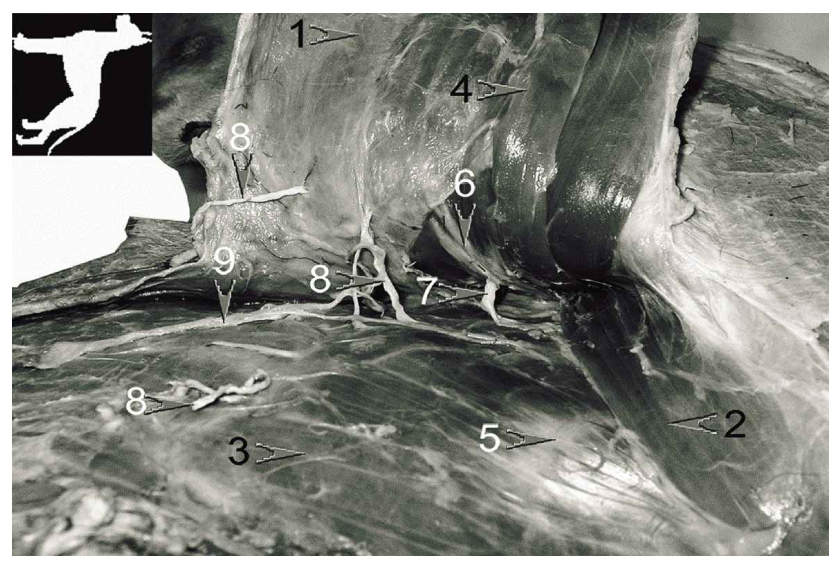

Fig. 2. Rigth side of the dog. M. latissimus dorsi (1). M. teres major (2). M. serratus ventralis caudalis (3). M. latissimus dorsi second venter (4). N. thoracicus longus (5). N. thoracodorsalis (joined to $A$. and V. thoracodorsalis) (6). N. intercostobrachialis (7). Nn. intercostalis, rami cutaneus (8). N. thoracicus lateralis (9).

\section{DISCUSSION}

In the absence of a study of the ontogeny or development of $M$. latissimus dorsi in the dog (Noden \& de Lahunta, 1990), explanations about the embryonic or genetic origin of this abnormalities remain speculative.

In birds M. latissimus dorsi also is biceps. Its two heads arise by cleavage in a single muscle primordium (Sullivan, 1962), although each part (pars interscapularis and pars metapatagialis) typically has a separate insertion on the humerus, all inervates by $N$. thoracodorsalis (Baumel et al., 1979).

In man (Lewis, 1902), also describes a pre-muscle mass, origin of: latissimus dorsi, teres major, pectoral, serratus anterior and levator scapulae. This mass is continuous with the arm pre-muscle sheath but its innervation is not common.

To share the same innervation, is a criterion to link different muscles with a common embryo origin. In this case this criterion occurs.

But we can use comparative anatomy of different groups of vertebrates to approach an explanation (Barone, 1972). The reptilian m. latissimus dorsi separates in mammal to three muscles: M. cutaneous trunci (part), M. teres major and M. latissimus dorsi (Liem et al., 2001; Kardong, 2002).

Then this $M$. latissimus dorsi second head in dog confirms the comparative anatomy explanation.

The thin second head of M. latissimus dorsi that we found, could be an intermediate step of these comparative anatomy changes from reptilian to mammal.

Pet and farm animals make excellent models for investigating tissue growth and developing surgical protocols. Man breast surgery and cardiomyoplasty, use dog M. latissimus dorsi as experimental model (Niinami et al., 1991; Yang et al., 1999). In this situations it is useful to know about our muscle find.

\section{ACKNOWLEDGEMENTS}

The authors thank Angel Hernado for preparation an handling the body of the dog.

GIL, J. \& OLIVARES, R.; Una segunda cabeza del músculo latissimus dorsi en un perro. Int. J. Morphol., 32(4):1464-1466, 2014.

RESUMEN: Este artículo describe el hallazgo del origen de un músculo gemelo no reportado. En un perro, los dos músculos latissimus dorsi, izquierdo y derecho, eran biceps. La segunda cabeza delgada del M. latissimus dorsi observada, podría ser un paso intermedio de los cambios de la anatomía comparada de reptil a mamífero. Conocer esta información puede ser útil para la cirugía de tórax y cardiomioplastía en el humano, donde el músculo latissimus dorsi del perro, es utilizado en forma experimental.

PAlabRAS CLAVE: Músculo; M. latissimus dorsi; Perro; Bíceps; Brazo.

\section{REFERENCES}

Barone, R. Traité de Zoologie. Paris, Masson, 1972.

Baumel, J. J.; King, A. S.; Lucas, A. M.; Breazile, J. E. \& Evans H. E. Nomina Anatomica Avium. London, Academic Press, 1979. pp.200.

Dyce, K. M.; Sack, W. O. \& Wensing, C. J. G. Anatomía 
Veterinaria. México D. F., McGraw-Hill Interamericana, 1999. pp.89.

Evans, H. E. Miller's Anatomy of the Dog. 3rd ed. Philadelphia, W. B. Saunders Company, 1993. pp.3245.

Gil, J.; Gimeno, M.; Laborda, J. \& Nuviala, J. Anatomía del Perro: Protocolos de Disección. Barcelona, Masson, 1997. pp.40,58.

Kardong, K. Vertebrates: Comparative Anatomy, Function, Evolution. $3^{\text {rd }}$ ed. New York, McGraw-Hill, 2002. pp.385-7.

Lewis, W. H. The development of arm in man. Am. J. Anat., 1:145-84, 1902.

Liem, K. F.; Bermis, W. E.; Walker, W. E. \& Grande, L. Functional anatomy of the vertebrates: An Evolutionary Perspective. $3^{\text {rd }}$ ed. London, Brooks/Cole, 2001. pp.3425.

Nickel, R.; Schummer, A.; Seiferle, E.; Wilkens, H.; Wille, K-H. \& Frewein, J. The Anatomy of the Domestic Animals. Volume 1. Berlin, Springer, 1986. pp.335, 345, 347, 349.

Niinami, H.; Pochettino, A.; Ruggiero, R.; Koroteyev, A.; Lu, H.; Hohenhaus, E.; Spanta, A. D.; Hammond, R. L. \& Stephenson, L. W. Canine latissimus dorsi cardiodouble myoplasty: acute feasibility study. J. Card. Surg., 6(1 Suppl.):124-31, 1991.

Noden, D. M. \& de Lahunta, A. Embriología de los animales domésticos. Madrid, Acribia Editorial, 1990. pp. 15369.

Schaller, O.; Constantinescu, G. M.; Habel, R. E.; Sack, W. O.; Simoens, P. \& de Vos, N. R. Nomenclatura Anatómica Veterinaria Ilustrada. Zaragoza, Acribia, 1992. pp.106.

Schwarze, E.; Schröder, L. \& Michel, G. Compendio de Anatomía Veterinaria. Zaragoza, Acribia, 1970. pp.201.

Sisson, S. \& Grossman, J. D. Anatomía de los Animales Domésticos. Barcelona, Salvat Editores, 1982. pp.1663.

Sullivan, G.E. Anatomy and embryology of the wing musculature of the domestic fowl (Gallus). Aust. J. Zool., 10(3):458-518, 1962.
Yang, D. \& Morris, S. F. Differences in intramuscular vascular connections of human and dog latissimus dorsi muscles. Ann. Thorac. Surg., 67(2):489-93, 1999.

Correspondence to:

Julio Gil

Department of Anatomy

Embryology and Animal Genetics

Faculty of Veterinary Medicine

University of Zaragoza

Zaragoza

SPAIN

Email address: juliogil@unizar.es

Received: 12-04-2014

Accepted: 24-10-2014 